\title{
RECENT DEVELOPMENT OF THE WAGE AND INCOME DISTRIBUTION IN THE CZECH REPUBLIC
}

\author{
Diana Bílková*
}

\begin{abstract}
:
The paper presents the development of monthly gross wages and wage distributions both by gender groups and for the total sample in the Czech Republic over the years 2002-2009. The first part deals with the development of sample characteristics of the level, differentiation and shape of the wage distribution in the research period, including characteristics of wage level forecasts for 2010 and 2011. Special attention is paid to the different behaviour of the wage distribution between men and women in the Czech Republic and the gender dependence of gross monthly wages. A comparison of the income level development in the Czech Republic with that of the other European Union countries in 2005-2009 is made in the final part of the paper. The comparison is drawn in relation to the income level development both in the original fifteen EU countries and the twelve newly-accepted EU member states.
\end{abstract}

Keywords: Wages in the Czech Republic, incomes in the European Union, wage distribution, income distribution, wage level, wage differentiation, income level, development of wage distribution

JEL Classification: C16, C22, H31

\section{Introduction}

Wages and incomes of households are being researched by economists in all developed countries as they reflect the standard of living of the population. The assessment of living standards, social security and equality of distribution of material possessions is conditional upon proper knowledge of the wage and income distribution among the population and its comparison from different socio-economic and time-spatial aspects. Statistical analysis of the development of the wage and income distribution is also supposed to be the basis for decision-making on the budget and social policy issues. A direct connection between incomes of the population and their purchasing power also increases the role of adequate monitoring of the level, structure and development of the wage and income distribution in identifying marketing opportunities for products of both long and short-term consumption. The knowledge of the wage and

* University of Economics, Prague, Faculty of Informatics and Statistics (bilkova@vse.cz).

Acknowledgement: The paper was supported by grant project IGS 24/2010 called "Analysis of the Development of Income Distribution in the Czech Republic since 1990 to the Financial Crisis and Comparison of this Development with the Development of the Income Distribution in Times of Financial Crisis - According to Sociological Groups, Gender, Age, Education, Profession Field and Region" from the University of Economics in Prague. 
income distribution allows to combine wage and income differentiation with sociopolitical considerations. Proportion analysis of low, medium or high wages or incomes is necessary, average values being insufficient for the above mentioned purpose.

The income and wage distribution has been paid a lot of research attention-Cunningham (2007), Rothschild (2005), Waltman (2000) and Wolff (2009) being among the most renowned authors. Methodology employed in an analysis of the income and wage distribution is extensively dealt with in the statistical literature. That is why standard statistical methods used in this research are not explicitly mentioned in the present paper. It offers the analysis of the wage distribution in the Czech Republic in recent years, monitoring its development in time and describing particular trends in terms of economic policy. It also aims at assessing the current financial standing of Czech households in international context, particularly in comparison with the European Union countries. Another statistical variable strongly correlated with wage is the income. Having employed a uniform methodology of the income distribution and outcomes of a statistical survey SILC (Statistics on Income and Living Conditions) run in the Czech Republic annually since 2005, international comparisons of Czech households' financial standing were conducted.

Having adopted a uniform methodology for the conversion of income used in all EU countries, the following variables were investigated: a gross monthly wage total, gross monthly wage by gender (between 2002 and 2009, in CZK) and annual net income (between 2005 and 2009, in EUR), i.e. nominal wage and nominal income. Relevant data were collected from Eurostat and the Czech Statistical Office websites, Microsoft Excel spreadsheet software and Statgraphics and Statistica programmes having been used for statistical data processing.

\section{Analysis of the Development of the Wage Distribution in the Czech Republic}

First, the development of gross monthly wages in the Czech Republic between 2002 and 2009 will be traced. Table 1 presents the development of the sample characteristics of absolute and relative variability (standard deviation and the coefficient of variation respectively) as well as that of the shape (the moment measure of skewness). Table 2 provides an overview of the development of the sample characteristic of location (median and arithmetic mean according to gender). Statistical sources explaining the construction of the above descriptive characteristics are abundant - Barber (1988), Bowerman, O'Connell (1997), Triola, (1989), Voelker, Orton, Adams (2001). From interpretation perspective, the standard deviation indicates how particular gross monthly wage values deviate on average from their arithmetic mean. The standard deviation is constructed as a quadratic average of these deviations. The coefficient of variation is the ratio of standard deviation to arithmetic mean, indicating (when multiplied by a hundred) percentage of standard deviation to arithmetic mean. It is usually expressed as a percentage. 
Table 1

Standard Deviation (in CZK), the Coefficient of Variation (in \%) and Moment Measure of Skewness (dimensionless) of Gross Monthly Wages from 2002 to 2009 in the Czech Republic

\begin{tabular}{|l|c|c|c|}
\hline Year & Standard deviation & Coefficient of variation & Skewness \\
\hline $\mathbf{2 0 0 2}$ & 14481 & 79.86 & 0.327 \\
\hline $\mathbf{2 0 0 3}$ & 15471 & 79.30 & 0.266 \\
\hline $\mathbf{2 0 0 4}$ & 16284 & 79.26 & 0.295 \\
\hline $\mathbf{2 0 0 5}$ & 16884 & 77.90 & 0.264 \\
\hline $\mathbf{2 0 0 6}$ & 19071 & 83.25 & 0.183 \\
\hline $\mathbf{2 0 0 7}$ & 20505 & 83.34 & 0.138 \\
\hline $\mathbf{2 0 0 8}$ & 22424 & 85.80 & 0.089 \\
\hline $\mathbf{2 0 0 9}$ & 25818 & 96.78 & 0.053 \\
\hline
\end{tabular}

Source: www.czso.cz + own research

Table 2

Median (in CZK) and Arithmetic Mean (in CZK) of Gross Monthly Wages from 2002 to 2009 in the Czech Republic according to Gender and Forecasts for the Years 2010 and 2011

\begin{tabular}{|l|c|c|c|c|c|c|}
\hline \multirow{2}{*}{ Year } & \multicolumn{2}{|c|}{ Total set } & \multicolumn{2}{c|}{ Set of men } & \multicolumn{2}{c|}{ Set of women } \\
\cline { 2 - 7 } & Median & Arit. mean & Median & Arit. mean & Median & Arit. mean \\
\hline $\mathbf{2 0 0 2}$ & 15.546 & 18.133 & 16.938 & 20.404 & 13.742 & 15.217 \\
\hline $\mathbf{2 0 0 3}$ & 16.717 & 19.510 & 18.221 & 21.983 & 14.838 & 16.404 \\
\hline $\mathbf{2 0 0 4}$ & 17.005 & 20.545 & 19.329 & 23.044 & 15.645 & 17.256 \\
\hline $\mathbf{2 0 0 5}$ & 18.600 & 21.674 & 20.265 & 24.271 & 16.443 & 18.221 \\
\hline $\mathbf{2 0 0 6}$ & 19.513 & 22.908 & 21.185 & 25.593 & 17.310 & 19.305 \\
\hline $\mathbf{2 0 0 7}$ & 20.909 & 24.604 & 22.850 & 27.489 & 18.322 & 20.684 \\
\hline $\mathbf{2 0 0 8}$ & 22.125 & 26.135 & 24.367 & 29.429 & 19.343 & 21.798 \\
\hline $\mathbf{2 0 0 9}$ & 22.231 & 26.677 & 24.158 & 29.953 & 19.797 & 22.414 \\
\hline $\begin{array}{l}\mathbf{2 0 1 0} \\
\text { (forecasts) }\end{array}$ & 23.713 & 28.306 & 25.568 & 31.898 & 20.731 & 23.680 \\
\hline $\begin{array}{l}\mathbf{2 0 1 1} \\
\text { (forecasts) }\end{array}$ & 24.742 & 29.629 & 26.462 & 33.490 & 21.508 & 24.746 \\
\hline
\end{tabular}

Source: www.czso.cz + own research

Table 2 also includes the predicted median and arithmetic mean of gross monthly wages by gender for the years 2010 and 2011. These predictions are based on the analysis of time series of monthly gross wages in the years 2002-2009 - Brockwell, Davis (2002), Cowpertwait, Metcalfe (2009), covering the period of economic crisis. Figures 1-6 provide an overview of trend functions that have been used for forecasting, including the value of the mean absolute percentage error. Figures 7 and 8 give 
a picture of the development of median and arithmetic mean of gross monthly wages of men and women in the period.

From Table 2 we can see the growth of median (medium wage) and arithmetic mean of gross monthly wages both in the group of men and women for almost entire period. The only exception is the end of the monitored period, namely that of economic crisis, when wage growth almost stopped. Table 3 shows the growth coefficient values of median and arithmetic mean of gross monthly wages in the period 2002-2009 according to gender.

Figure 1:

Trend Analysis (median - total)

Linear trend $=14449.0+1029.29 t$,

MAPE $=1.36798$

(X 1000)

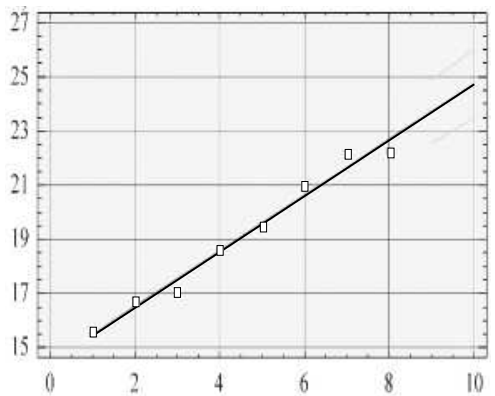

Source: own research

Figure 3:

Trend Analysis (median - men)

Quadratic trend $=15630.3+1293.15 \mathrm{t}+$ $-20.994 t^{\wedge} 2$

MAPE=1.17425

(X 1000)

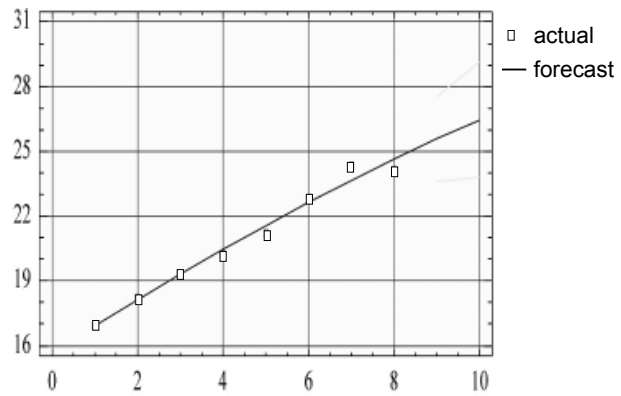

Source: own research
Figure 2:

Trend Analysis (arit. mean - total)

Quadratic trend $=16911.8+1214.68 \mathrm{t}+$

$5.70238 \mathrm{t}^{\wedge} \mathbf{2}$; MAPE $=\mathbf{0 . 8 2 0 7 2 2}$

(X 1000)

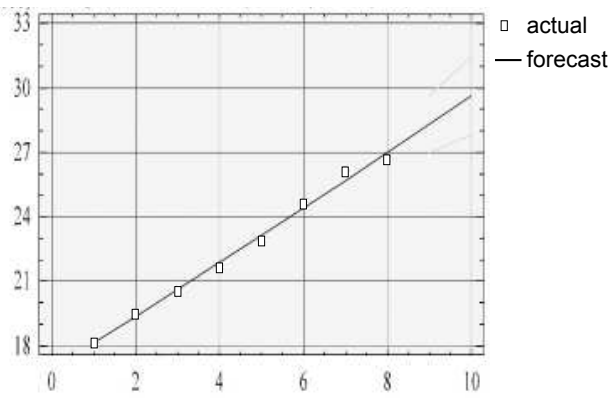

Source: own research

Figure 4:

Trend Analysis (arit. mean - men)

Quadratic trend $=19177.4+1253.17 \mathrm{t}+$

$17.8095 \mathrm{t}^{\wedge} 2$

MAPE $=0.924196$

(X 1000)

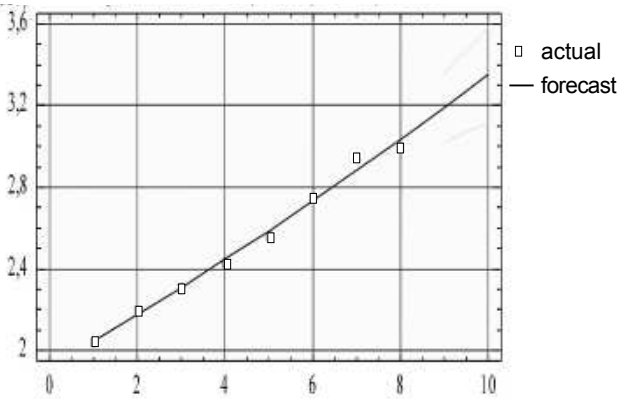

Source: own research 
Figure 5:

Trend Analysis (median - women)

Quadratic trend $=12823.1+970.381 \mathrm{t}+$ $-10.1905 t^{\wedge} 2$

\section{MAPE $=0.553426$}

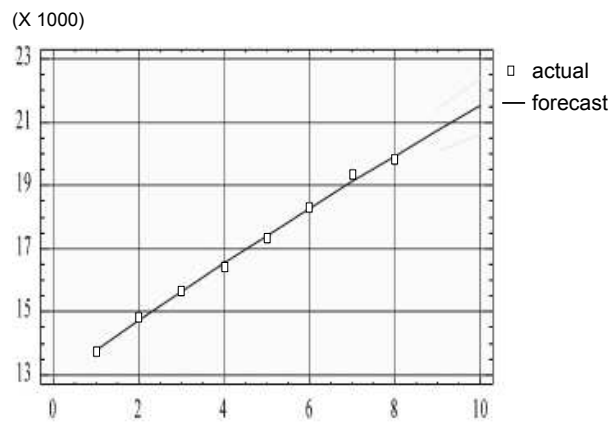

Figure 6:

Trend Analysis (arit. mean - women)

Quadratic trend $=14174.8+1047.1 \mathrm{t}+$ $1.00595 \mathrm{t}^{\wedge} 2$

MAPE $=0.715506$

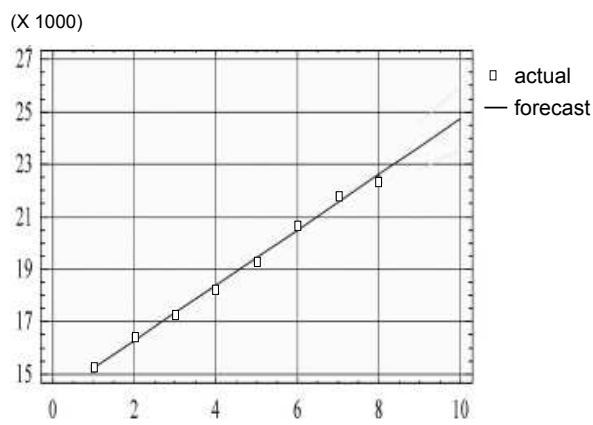

Source: own research

Figure 7

Development of the Median of Gross Monthly Wages of Men and Women in 2002-2009 (in CZK)

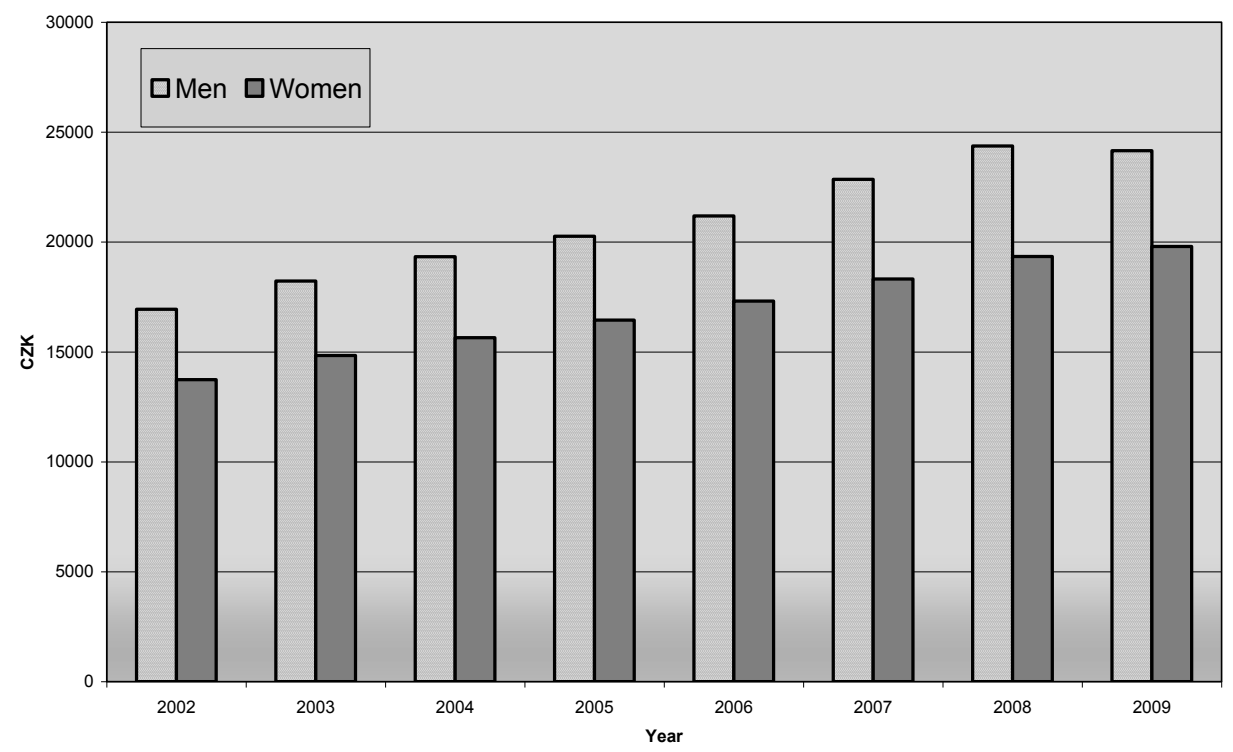

Source: own research 
Figure 8

Development of the Arithmetic Mean of Gross Monthly Wages of Men and Women in 2002-2009 (in CZK)

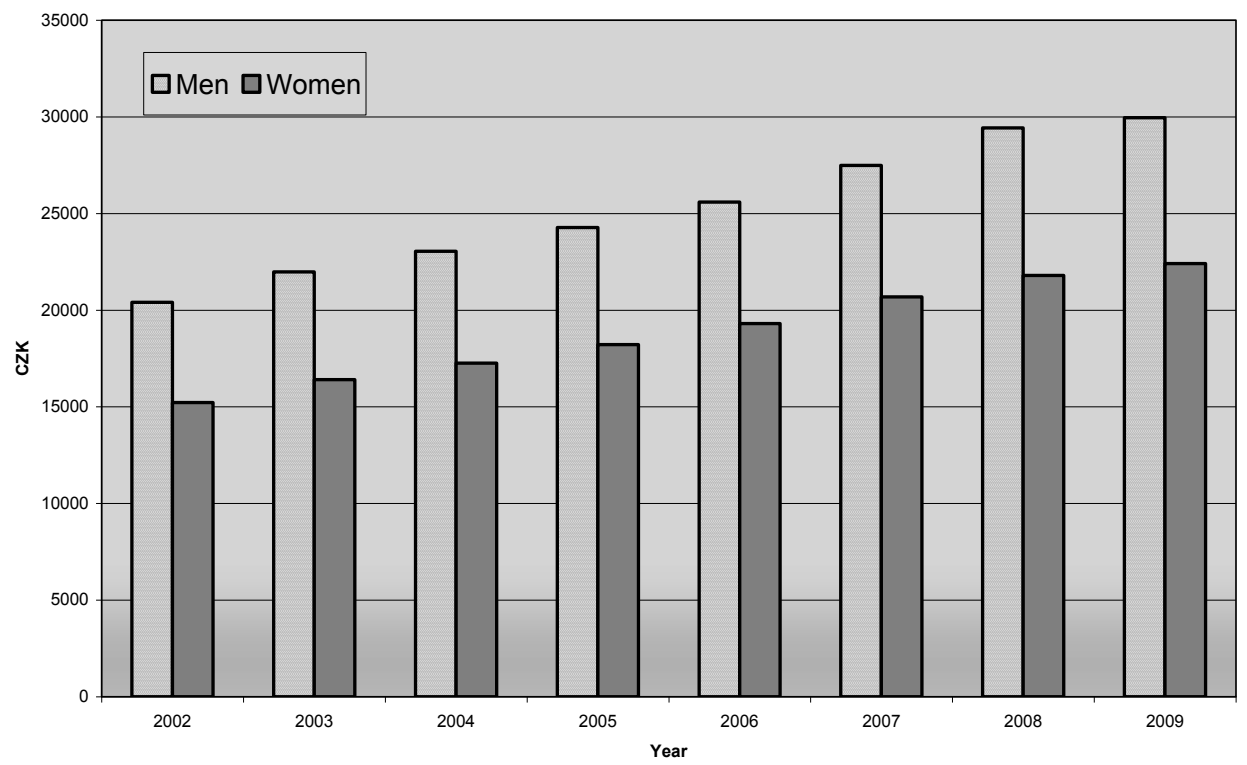

Source: own research

Table 3

Growth Coefficient of Median and Arithmetic Mean of Gross Monthly Wages in the Period 2002-2009 in the Czech Republic according to Gender

\begin{tabular}{|c|c|c|c|c|c|c|c|c|c|c|c|c|}
\hline \multirow{3}{*}{$\begin{array}{l}\text { Year } \\
2002\end{array}$} & \multicolumn{4}{|c|}{ Total set } & \multicolumn{4}{|c|}{ Set of men } & \multicolumn{4}{|c|}{ Set of women } \\
\hline & \multicolumn{2}{|c|}{ Median } & \multicolumn{2}{|c|}{ Arit. mean } & \multicolumn{2}{|c|}{ Median } & \multicolumn{2}{|c|}{ Arit. mean } & \multicolumn{2}{|c|}{ Median } & \multicolumn{2}{|c|}{ Arit. mean } \\
\hline & - & \multirow{7}{*}{$\stackrel{\check{\varphi}}{\circ}$} & - & \multirow{7}{*}{$\stackrel{\overbrace{}}{\varrho}$} & - & \multirow{7}{*}{$\begin{array}{l}\underset{8}{0} \\
\stackrel{-}{-}\end{array}$} & - & \multirow{7}{*}{$\stackrel{\mathscr{ׁ}}{\mathscr{0}}$} & - & \multirow{7}{*}{ 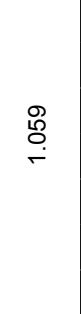 } & - & \multirow{7}{*}{$\underset{\dddot{O}}{\stackrel{0}{-}}$} \\
\hline 2003 & 1.075 & & 1.076 & & 1.076 & & 1.077 & & 1.080 & & 1.078 & \\
\hline 2004 & 1.017 & & 1.053 & & 1.061 & & 1.048 & & 1.054 & & 1.052 & \\
\hline 2005 & 1.094 & & 1.055 & & 1.048 & & 1.053 & & 1.051 & & 1.056 & \\
\hline 2006 & 1.049 & & 1.057 & & 1.045 & & 1.054 & & 1.053 & & 1.059 & \\
\hline 2007 & 1.072 & & 1.074 & & 1.079 & & 1.074 & & 1.058 & & 1.071 & \\
\hline 2008 & 1.058 & & 1.062 & & 1,066 & & 1.071 & & 1.056 & & 1.054 & \\
\hline 2009 & 1.005 & 1.005 & 1.021 & 1.021 & 0.991 & 0.991 & 1.018 & 1.018 & 1.023 & 1.023 & 1.028 & 1.028 \\
\hline $\begin{array}{l}\varnothing \\
(02-09)\end{array}$ & \multicolumn{2}{|c|}{1.052} & \multicolumn{2}{|c|}{1.057} & \multicolumn{2}{|c|}{1.052} & \multicolumn{2}{|c|}{1.056} & \multicolumn{2}{|c|}{1.054} & \multicolumn{2}{|c|}{1.057} \\
\hline
\end{tabular}

Source: own research 
It is clear that the growth rate in both median and average was markedly higher before than during the economic crisis. The average growth rate of median and arithmetic mean is around $6 \%$ of all the researched groups before the financial crisis, not exceeding $3 \%$ between 2008 and 2009. During the crisis, there was even a decrease in the median of gross monthly wages of men. A significant difference between the wage levels of men and women is observable from Tables 2 and 3 and Figures 7 and 8, showing a growing trend in time, particularly in the case of arithmetic mean. Opening up "the wage gap" between men and women seems to be obvious. On the other hand, the average year growth rate of median and arithmetic mean of gross monthly wages is comparable (5-6\%) for all researched groups over the entire period.

Table 4 provides an overview of the statistical dependence of gross monthly wage upon gender. Having applied a test analysis of variance known as ANOVA (one-factor) - Roberts, Russo (1999), Turner, Thayer (2001), the above mentioned dependence was verified for each year of the period. The gross monthly wage dependence upon gender was demonstrated for virtually any commonly used significance level $(\alpha=0.05)$ with regard to large sample sizes typical for the research of the wage and income distribution. However, from Table 4 can be seen that it is a considerably weak intensity dependence. In terms of variance analysis, the decomposition of total variability into both intragroup and intergroup variability is performed, the source of dependence being just the intergroup variability. Table 4 indicates that the intragroup variability of gross monthly wages (variability within two single files of men and women) clearly prevails over the intergroup variability (that between two single files of men and women). It agrees in favour of a very weak dependence of gross monthly wage upon gender, the values of ratio determination being very low (2-3\%) in Table 4 (dark). Some relevant sample characteristics of variance analysis were estimated from the interval frequency distribution. On that score, neither total standard deviation nor the total coefficient of variation arise entirely consistent with Table 1 which shows more accurate values of these characteristics.

Table 1 presents the development of characteristics of variability and the shape of the wage distribution, indicating an increase in the characteristic of absolute variability (standard deviation) in time. Therefore, the data cannot be considered homoscedastic within the meaning of the same variability in the same distribution. The characteristic of relative variability (the coefficient of variation) increases in time while the skewness of the distribution decreases markedly, speaking in favour of the people with exceptionally high wages. This group is gradually growing. 
Table 4

Variance Components (intragroup and intergroup variance)

\begin{tabular}{|c|c|c|c|c|c|c|}
\hline Year & $\begin{array}{c}\text { Total } \\
\text { average }\end{array}$ & $\begin{array}{c}\text { Average } \\
\text { variance } \\
\text { (intragroup) }\end{array}$ & $\begin{array}{c}\text { Variance } \\
\text { of averages } \\
\text { (intergroup) }\end{array}$ & $\begin{array}{c}\text { Total } \\
\text { variance }\end{array}$ & $\begin{array}{c}\text { Total } \\
\text { standard } \\
\text { deviation }\end{array}$ & $\begin{array}{c}\text { Total variation } \\
\text { coefficient }\end{array}$ \\
\hline \multirow[t]{2}{*}{2002} & \multirow[t]{2}{*}{18426} & \multirow{2}{*}{$\begin{array}{c}238691485 \\
97.35 \%\end{array}$} & 6509077 & \multirow{2}{*}{$\begin{array}{c}245200563 \\
100 \%\end{array}$} & \multirow[t]{2}{*}{15659} & \multirow[t]{2}{*}{$84.55 \%$} \\
\hline & & & $2.65 \%$ & & & \\
\hline \multirow[t]{2}{*}{2003} & \multirow[t]{2}{*}{19510} & \multirow{2}{*}{$\begin{array}{c}229747293 \\
96.76 \%\end{array}$} & 7705170 & \multirow{2}{*}{$\begin{array}{c}237452464 \\
100 \%\end{array}$} & \multirow[t]{2}{*}{15409} & \multirow[t]{2}{*}{$79.15 \%$} \\
\hline & & & $3.24 \%$ & & & \\
\hline \multirow[t]{2}{*}{2004} & \multirow[t]{2}{*}{20545} & \multirow{2}{*}{$\begin{array}{c}239098765 \\
96.62 \%\end{array}$} & 8373766 & \multirow{2}{*}{$\begin{array}{c}247472532 \\
100 \%\end{array}$} & \multirow[t]{2}{*}{15731} & \multirow[t]{2}{*}{$77.92 \%$} \\
\hline & & & $3.38 \%$ & & & \\
\hline \multirow[t]{2}{*}{2005} & \multirow[t]{2}{*}{21674} & \multirow{2}{*}{$\begin{array}{c}257930913 \\
96.57 \%\end{array}$} & 9148315 & \multirow{2}{*}{$\begin{array}{c}267079229 \\
100 \%\end{array}$} & \multirow[t]{2}{*}{16343} & \multirow[t]{2}{*}{$76.75 \%$} \\
\hline & & & $3.43 \%$ & & & \\
\hline \multirow[t]{2}{*}{2006} & \multirow[t]{2}{*}{22908} & \multirow{2}{*}{$\begin{array}{c}327282427 \\
97.07 \%\end{array}$} & 9884068 & \multirow{2}{*}{$\begin{array}{c}337166495 \\
100 \%\end{array}$} & \multirow[t]{2}{*}{18362} & \multirow[t]{2}{*}{$81.7 \%$} \\
\hline & & & $2.93 \%$ & & & \\
\hline \multirow[t]{2}{*}{2007} & \multirow[t]{2}{*}{24604} & \multirow{2}{*}{$\begin{array}{c}382190276 \\
97.06 \%\end{array}$} & 11569071 & \multirow{2}{*}{$\begin{array}{c}393759347 \\
100 \%\end{array}$} & \multirow[t]{2}{*}{19843} & \multirow[t]{2}{*}{$82.08 \%$} \\
\hline & & & $2.94 \%$ & & & \\
\hline \multirow[t]{2}{*}{2008} & 26349 & 463318489 & 14772717 & 478091205 & 21865 & $84.52 \%$ \\
\hline & & $96.91 \%$ & $3.09 \%$ & $100 \%$ & & \\
\hline 2009 & 26677 & 611711588 & 14200564 & 625912151 & 25018 & $95.21 \%$ \\
\hline & & $97.73 \%$ & $2.27 \%$ & $100 \%$ & & \\
\hline
\end{tabular}

Source: www.czso.cz + own research

Figure 9

Probability Density Function of the Model Distribution of Gross Monthly Wage in 2005-2009 in the Czech Republic

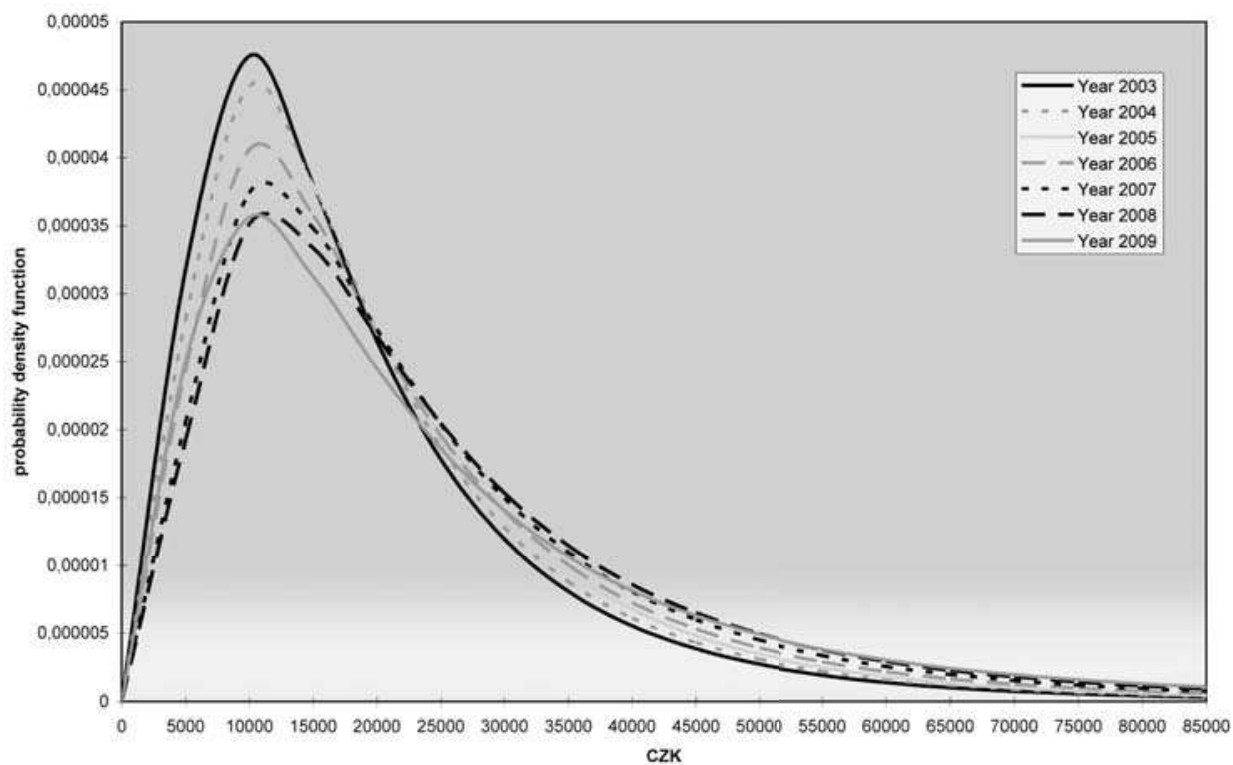

Source: own research 
Figure 10

Development of Extreme Quartiles of Gross Monthly Wage in the Czech Republic in 2002-2009 (in CZK)

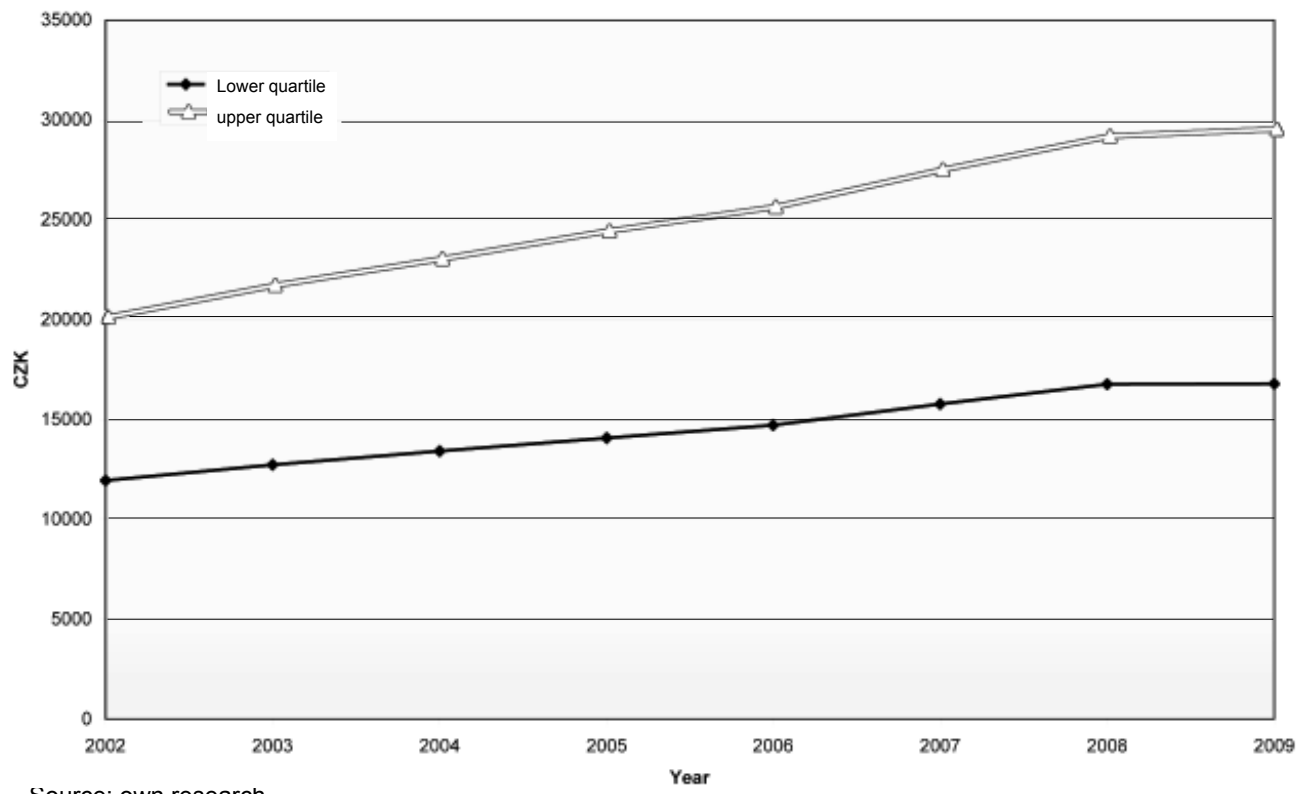

Source: own research

Figure 11

Development of Extreme Deciles of Gross Monthly Wage in the Czech Republic in 2002-2009 (in CZK)

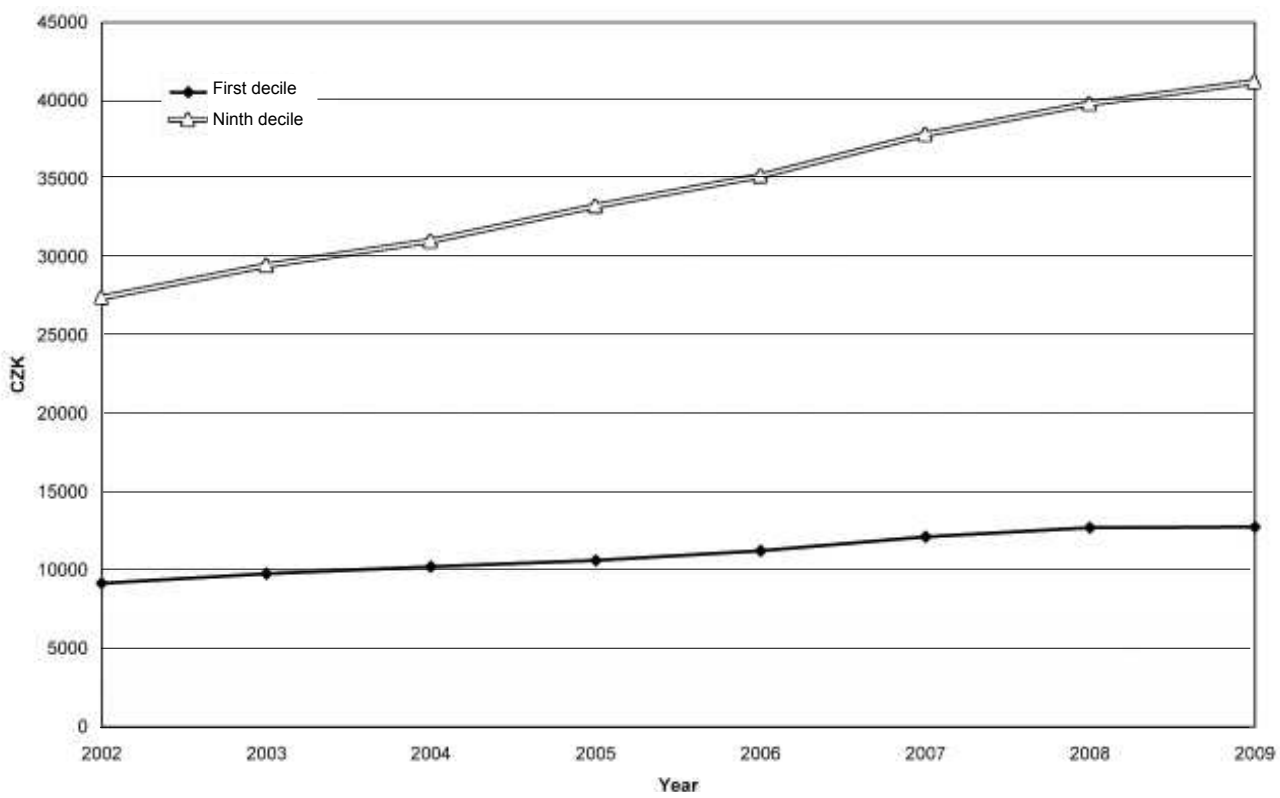

Source: own research 
A vivid picture of the development of the wage distribution in the Czech Republic over the years 2002-2009 is also offered by Figure 9, displaying model (theoretical) distributions of gross monthly wage (as histograms of the interval frequency distribution from the samples cannot be used for an unequal width of intervals). Model distributions represent probability density functions of three-parametric lognormal curves - Bartošová (2006), Bílková (2008), with parameters estimated using the moment method of parameter estimation - Bílková (2008). This method is applicable with sufficient accuracy to large samples being used for the wage distribution analysis. Figure 9 shows the same values as Table 1 (and in part also Table 2), indicating a gradual increase in the level of the wage distribution in the period following the economic crisis. During the crisis, the rise in wage level virtually stopped. The variability of the wage distribution is increasing steadily while the skewness and kurtosis are gradually decreasing in time. The number of people with high wages escalates over time. During the economic recession, the level of the wage distribution does not practically change, its differentiation is, however, increasing significantly. The skewness of the wage distribution slightly decreases in this period, its kurtosis remaining virtually unchanged (see Figure 9).

Figure 10 indicates the development of extreme quartiles, Figure 11 presents the development of extreme deciles. Fifty percent of monthly medium gross wages lies within the interval between the lower and upper quartile. Figure 10 shows the development of this interval in the investigated period; the interval gradual expansion is noticeable. Figure 11 provides an overview of the development of extreme deciles - the first decile, separating ten percent of the lowest wages, and the ninth decile, separating ten percent of the highest wages. Eighty percent of monthly medium gross wages lies within the interval between the first and the ninth decile. Figure 11 shows the development of this interval during the monitored period. It is also expanding in time (see Figure 11). A slowing down of the increase in both the extreme wage quartiles and deciles during the economic recession is also observable from Figures 10 and 11. Extreme percentiles (the first and the ninety-ninth ones) are usually used as the characteristics of a minimum and maximum wage. As all the above mentioned quantiles were estimated from the interval frequency table of extreme open intervals, the calculation of these extreme percentiles would be considerably inaccurate. That is why extreme percentiles are not presented.

\section{Development of the Income Distribution - Comparison with the EU Countries}

Income is a variable strongly correlating with that of wage. The variable of income is thus used to compare the development of financial standing of households in the Czech Republic with those in other EU countries. It is consistent with a uniform methodology employed in all EU countries when carrying out surveys and personal income calculations. The researched variable is the personal net annual income in EUR (not per capita; the differences consisting in calculations applied - methodology of conversion of the EU was used in our data). 
Figure 12 shows the current EU member states and membership candidates (dark colour). The original "European Twelve" (comprising Germany, France, Italy, Belgium, Luxemburg, the Netherlands, the United Kingdom, Ireland, Denmark, Greece, Spain and Portugal) enlarged by three countries (Austria, Finland and Sweden) in 1995; the development of the income distribution in the Czech Republic being compared with that of this particular "European Fifteen". (Further EU enlargements brought in the Czech Republic, Slovakia, Slovenia, Hungary, Poland, Lithuania, Latvia, Estonia, Cyprus and Malta in 2004 and Romania and Bulgaria in 2007, Turkey, Iceland, Croatia and Macedonia being among the current EU candidates.)

Figure 12

\section{European Union Countries}

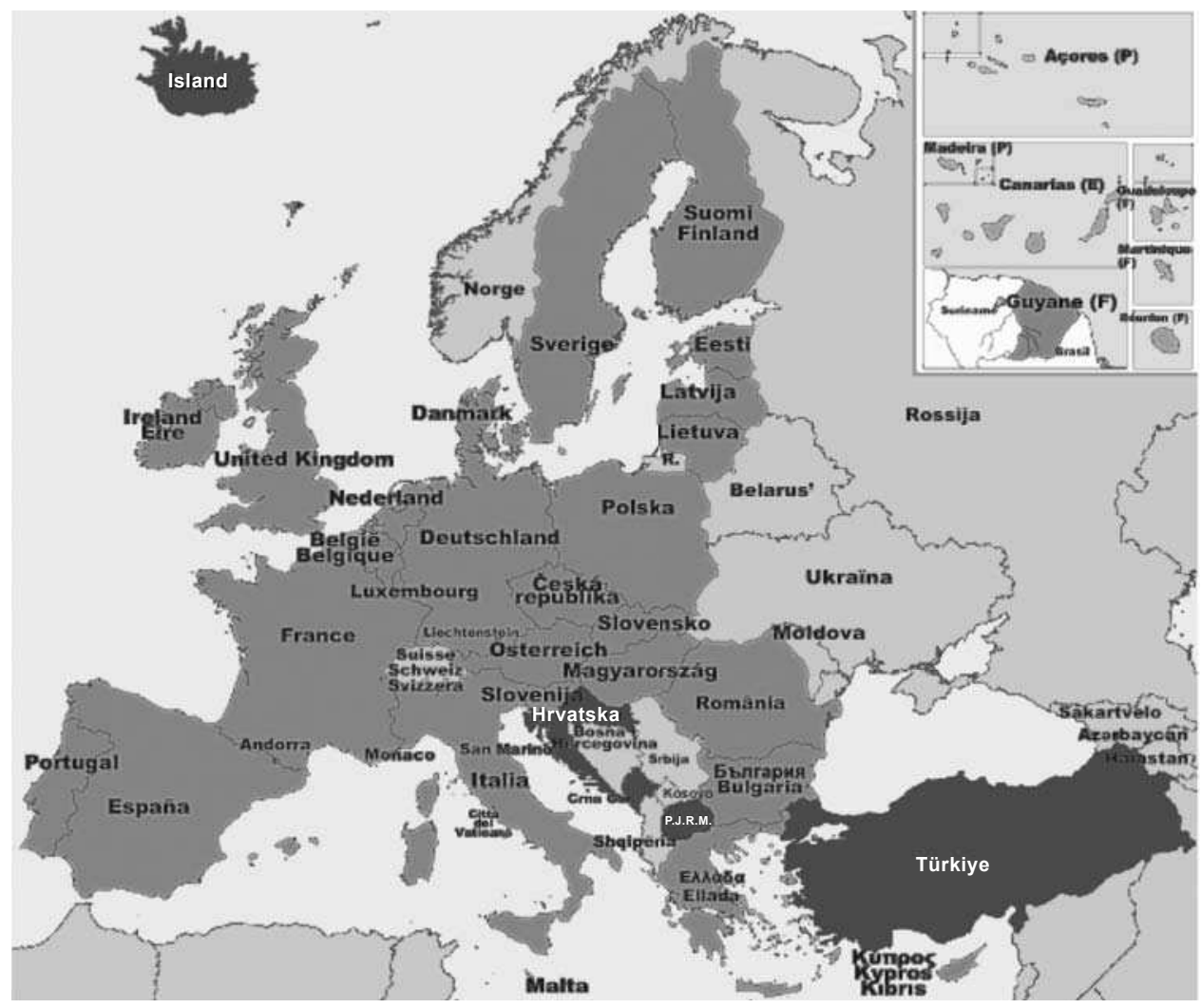

Source: http://epp.eurostat.ec.europa.eu/portal/page/portal/eurostat/home 
Table 5

Development of the Median of Equivalised Net Annual Income in 2005-2009 (in EUR)

\begin{tabular}{|c|c|c|c|c|c|}
\hline \multirow[b]{2}{*}{ Country } & \multicolumn{5}{|c|}{ Year } \\
\hline & 2005 & 2006 & 2007 & 2008 & 2009 \\
\hline $\begin{array}{l}\text { European Union } \\
\text { (all } 27 \text { countries) }\end{array}$ & 12.975 & 13.188 & 13.900 & 14.598 & 14.622 \\
\hline $\begin{array}{l}\text { European Union } \\
\text { (15 countries) } \\
\text { Member states on } 31 \\
\text { December } 1995\end{array}$ & 15.465 & 15.575 & 16.545 & 17.282 & 17.290 \\
\hline $\begin{array}{l}\text { European Union } \\
\text { (12 countries) } \\
\text { New member states }\end{array}$ & - & - & 3.255 & 3.868 & 4.557 \\
\hline Austria & 18.001 & 17.854 & 18.156 & 19.011 & 19.886 \\
\hline Belgium & 16.581 & 17.213 & 17.566 & 17.985 & 19.313 \\
\hline Bulgaria & - & 1.383 & 1.481 & 2.171 & 2.828 \\
\hline Cyprus & 13.157 & 14.536 & 16.014 & 16.765 & 17.432 \\
\hline Czech Republic & 4.233 & 4.802 & 5.423 & 6.068 & 7.295 \\
\hline Denmark & 22.124 & 22.663 & 23.341 & 24.161 & 24.933 \\
\hline Estonia & 2.981 & 3.639 & 4.448 & 5.547 & 6.209 \\
\hline Finland & 17.496 & 18.345 & 18.703 & 19.815 & 20.962 \\
\hline France & 15.946 & 16.209 & 16.441 & 18.984 & 19.760 \\
\hline Germany & 16.393 & 15.663 & 17.777 & 18.309 & 18.586 \\
\hline Greece & 9.417 & 9.850 & 10.200 & 10.800 & 11.496 \\
\hline Hungary & 3.447 & 3.850 & 3.936 & 4.400 & 4.739 \\
\hline Ireland & 18.798 & 19.757 & 22.065 & 22.995 & 22.445 \\
\hline Italy & 14.352 & 14.524 & 15.011 & 15.639 & 15.637 \\
\hline Latvia & 2.204 & 2.534 & 3.350 & 4.832 & 5.474 \\
\hline Lithuania & 2.058 & 2.534 & 3.276 & 4.169 & 4.815 \\
\hline Luxembourg & 28.396 & 29.480 & 29.892 & 30.917 & 31.764 \\
\hline Malta & 8.047 & 8.747 & 9.100 & 9.558 & 9.933 \\
\hline Netherlands & 17.001 & 17.263 & 18.244 & 19.522 & 20.156 \\
\hline Poland & 2.533 & 3.111 & 3.502 & 4.155 & 5.097 \\
\hline Portugal & 7.195 & 7.311 & 7.573 & 8.143 & 8.282 \\
\hline Spain & 10.600 & 11.480 & 12.038 & 12.950 & 13.300 \\
\hline Romania & - & - & 1.657 & 1.953 & 2.162 \\
\hline Slovenia & 8.797 & 9.317 & 9.907 & 10.893 & 11.864 \\
\hline Slovakia & 2.830 & 3.313 & 3.972 & 4.792 & 5.671 \\
\hline Sweden & 17.499 & 17.991 & 18.845 & 20.573 & 21.248 \\
\hline United Kingdom & 18.540 & 19.512 & 21.014 & 18.923 & 16.256 \\
\hline
\end{tabular}

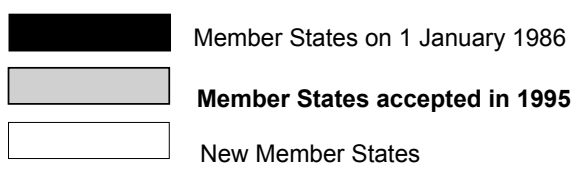

Source: http://epp.eurostat.ec.europa.eu/portal/page/portal/eurostat/home 
Table 5 presents the development of median of net annual income in the EU states in the years 2005-2009 (nominal income). The year 2005 was chosen as the starting point of income time series as the first sample SILC survey had been carried out in the Czech Republic then. The twelve original EU members are marked in black, the 1995 accession countries in grey and the remaining twelve new EU member states having acceded since 2000 (mostly post-communist states of the former Soviet bloc) are shown on a white background in Table 5. The development of the median of net annual income in the European Union is shown in three separate graph lines in Figure 13 - for all current EU countries, the fifteen original members (having joined the EU by 31 December 1995) and the twelve new member states. However, Eurostat data on new EU members has been available only since 2007. Their low net annual income, in comparison with the fifteen original member states, is clearly evident from Figure 13. It can be calculated from Table 5 that the 2007 median net annual income in the new EU member states accounted for about $20 \%$ of that of fifteen original members, this share rising to around $22 \%$ and $26 \%$ in 2008 and 2009 respectively.

It is obvious that population incomes (nominal) in the new EU member states are still almost five times lower than those in the "European Fifteen" countries, the two exceptions among the newly accepted countries being Cyprus and Malta, whose median net annual income is markedly higher, as indicated in Figure 15. The increase in the percentage rate of net annual income of the new EU members' population compared to net annual income of the original fifteen countries' population is rather slow.

Figure 13

Development of the Median of Net Annual Income in 2005-2009 (in EUR)

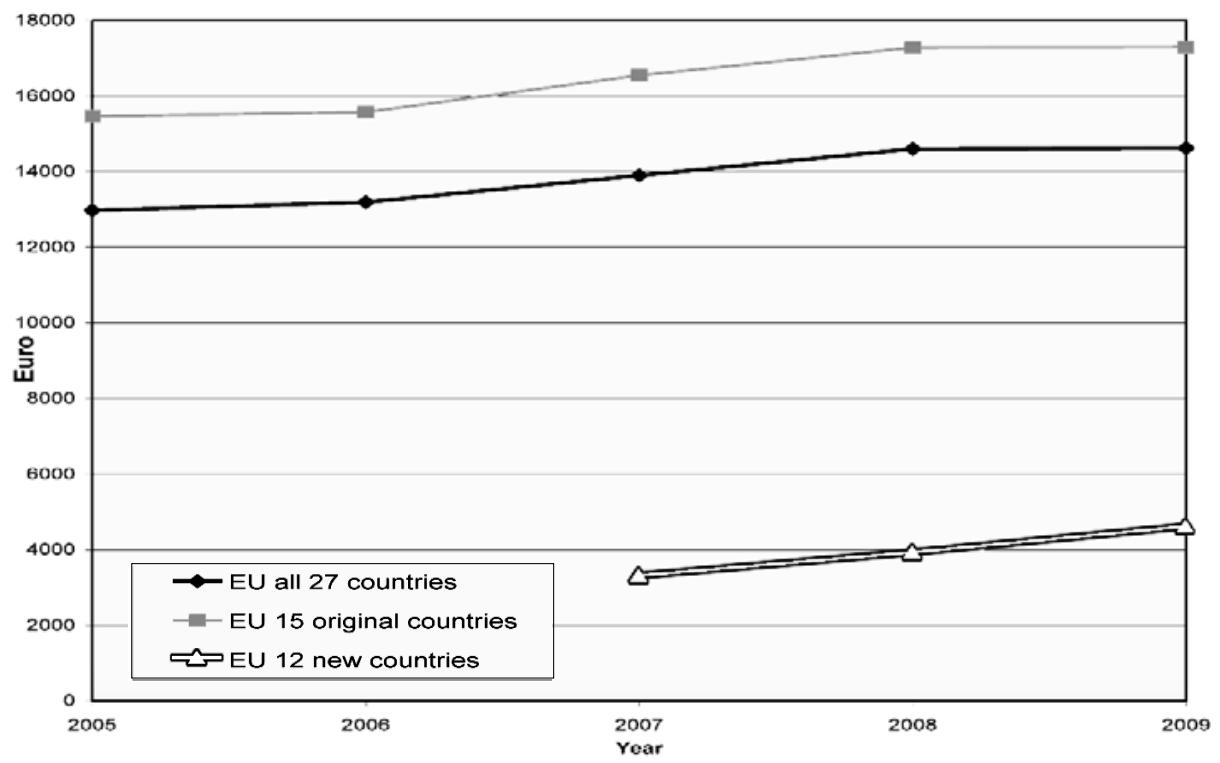

Source: own research 
Figure 14

Development of the Median of Net Annual Income in 2005-2009 - Member States on 31 December 1995 (in EUR)

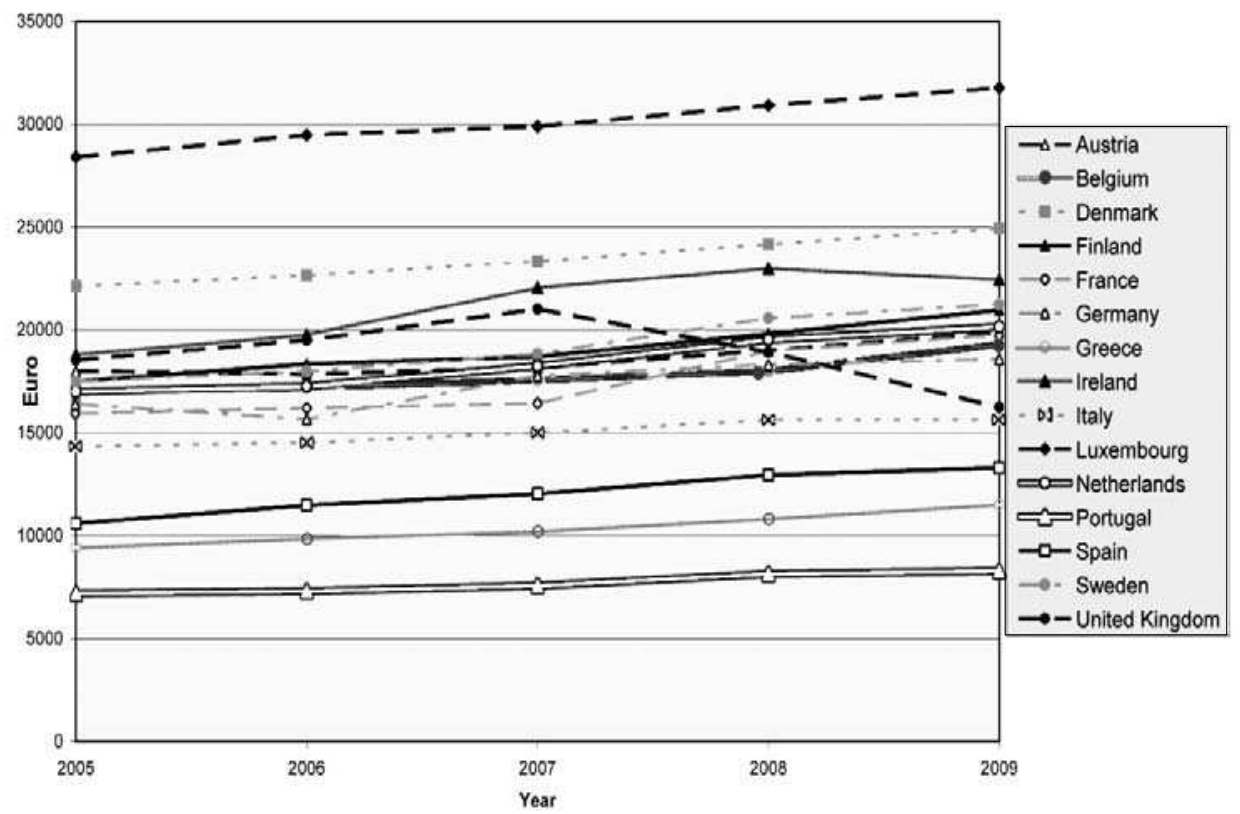

Source: own research

Figure 15

Development of the Median of Net Annual Income in 2005-2009 - New Member States (in EUR)

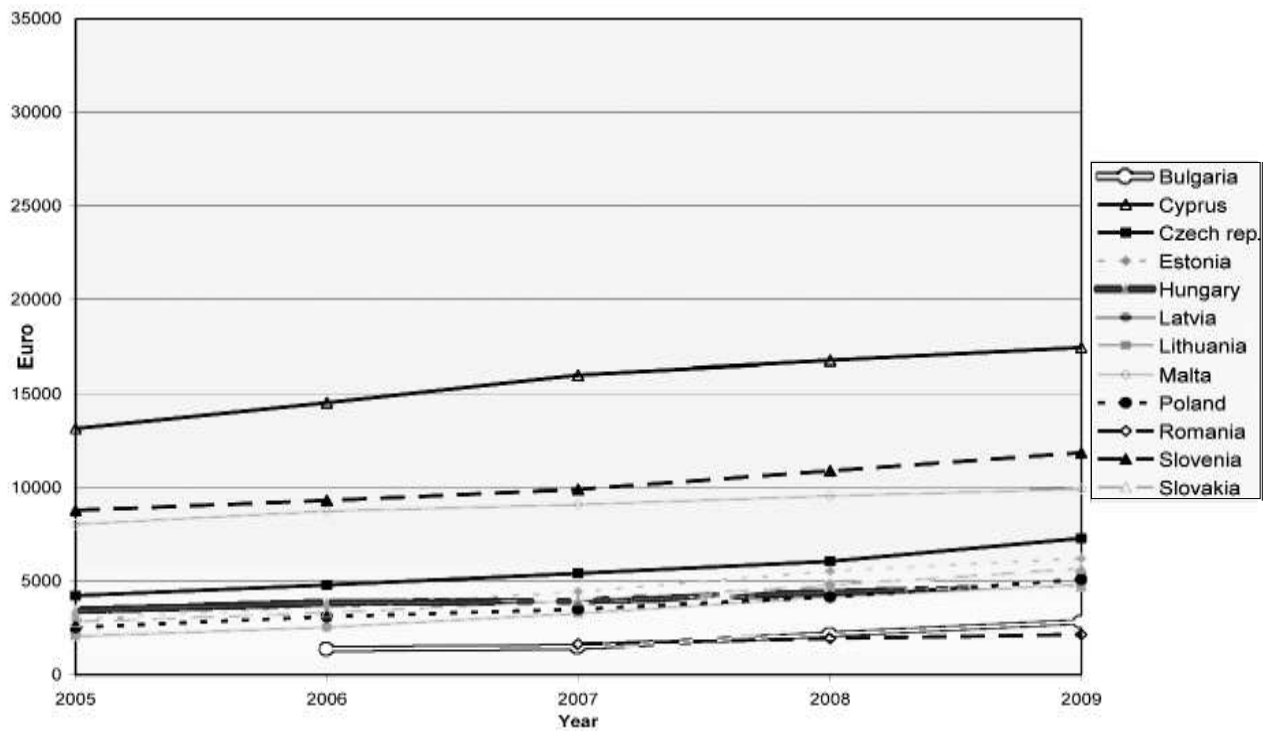

Source: own research 
Figures 14 and 15 show the development of the median of net annual income in both the original fifteen (Figure 14) and the twelve new (Figure 15) EU member states. The two figures are not intended to compare household income between particular countries, indicating, however, significantly higher net annual income of the original EU countries' population than that of the twelve new members over the period 2005-2009. Taking into account only the income factor of the living standard in 2009 , it can be deduced from Table 5 and Figure 16 that the best-paid population is in Luxembourg, followed by Denmark, Ireland and the Netherlands. The Portuguese and Greeks, on the other hand, are the least well-off citizens of the original fifteen EU states. As for the new EU members, Cyprus, Slovenia, Malta and the Czech Republic (the best post-communist country, along with Slovenia) are the income leaders, the inhabitants of Romania, Bulgaria, Hungary and Lithuania earning the lowest incomes across the European Union. On the other hand, as it is recorded in Table 6, twelve new EU members show a markedly higher growth rate of median net annual income (an average growth of $18.32 \%$ per annum) than the original fifteen member states (an average annual growth of $2.83 \%$ ) between 2005 and 2009 .

Figure 16

Median of Net Annual Income in 2009 (in EUR)

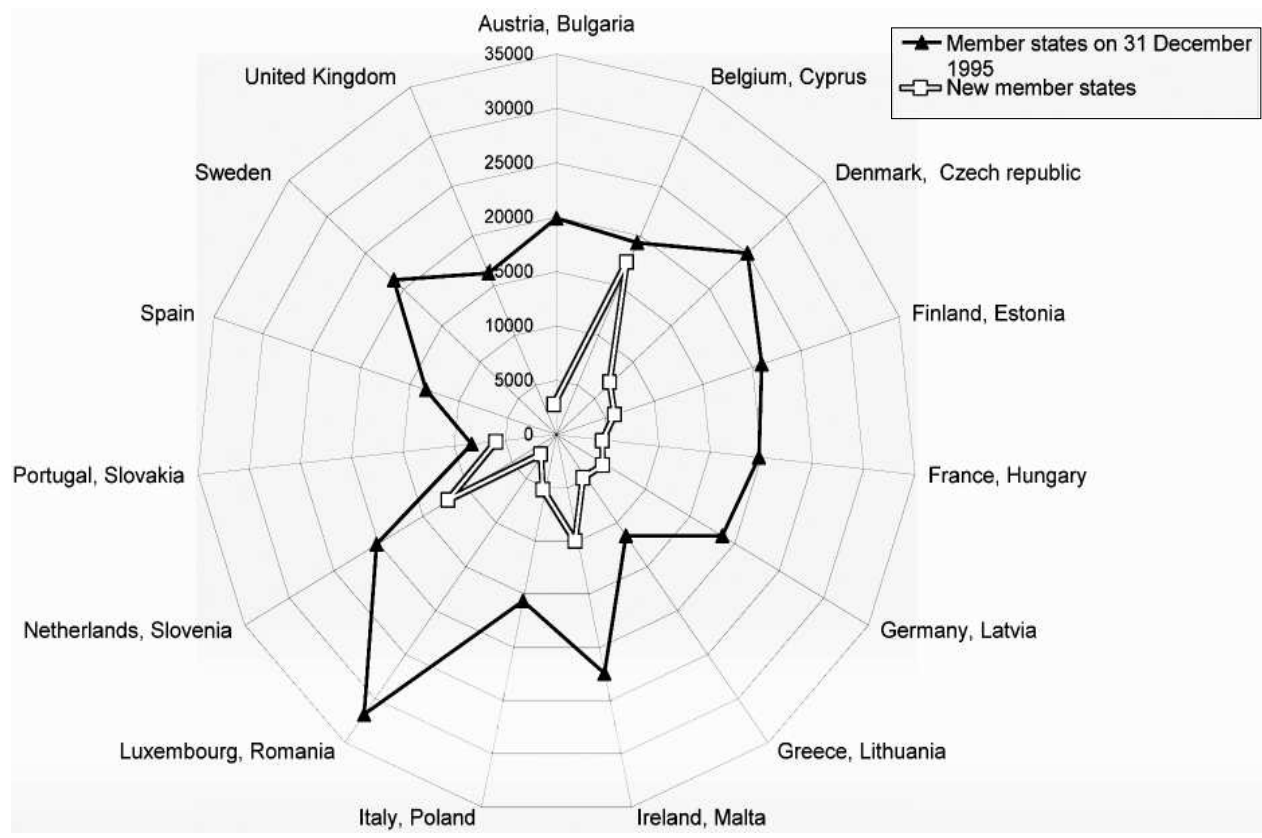

Source: own research

In Table 7, the countries acceding to the EU in 1995 and the former non-communist countries among new members are highlighted in grey and black respectively. A decline in the median of net annual income reflected by the average growth coefficient in 
the years 2005-2009 is only the case of the United Kingdom (an average decrease of $3.2 \%$ per annum), the net annual income median for all the other countries showing an average growth each year. Bulgaria, Latvia and Lithuania demonstrate a faster income median growth rate in the given period (on average of $23.7-26.9 \%$ per annum). The conclusion can be drawn that a very low income level in certain countries is not necessarily accompanied by an extremely low rate of income growth, while countries with higher levels of income show a lower rate of income growth.

Table 6

Average Growth Coefficient of the Net Annual Income Median in 2005-2009 - European Union

\begin{tabular}{|c|c|c|c|}
\hline Countries & $\begin{array}{c}\text { European Union } \\
\text { (27 countries) }\end{array}$ & $\begin{array}{c}\text { European Union } \\
\text { (15 countries) Member States on } \\
\text { 31 December 1995 }\end{array}$ & $\begin{array}{c}\text { European Union } \\
\text { (12 countries) } \\
\text { New Member States }\end{array}$ \\
\hline $\begin{array}{c}\text { Average } \\
\text { growth } \\
\text { rate }\end{array}$ & 1.030326 & 1.028280 & 1.183216 \\
\hline
\end{tabular}

Source: own research

Table 7

Average Growth Coefficent of the Net Annual Income Median in 2005-2009

\begin{tabular}{|l|c|l|c|}
\hline \multicolumn{2}{|c|}{$\begin{array}{c}\text { European Union } \\
\text { (15 countries) }\end{array}$} & \multicolumn{2}{c|}{$\begin{array}{c}\text { European Union } \\
\text { (12 countries) } \\
\text { New Member States }\end{array}$} \\
\hline Country & $\begin{array}{c}\text { Average growth } \\
\text { Rate }\end{array}$ & Country & $\begin{array}{c}\text { Average growth } \\
\text { rate }\end{array}$ \\
\hline Austria & 1.025 & Bulgaria & 1.269 \\
\hline Belgium & 1.039 & Cyprus & 1.073 \\
\hline Denmark & 1.030 & Czech Republic & 1.146 \\
\hline Finland & 1.046 & Estonia & 1.201 \\
\hline France & 1.055 & Hungary & 1.083 \\
\hline Germany & 1.032 & Latvia & 1.255 \\
\hline Greece & 1.051 & Lithuania & 1.237 \\
\hline Ireland & 1.045 & Malta & 1.054 \\
\hline Italy & 1.022 & Poland & 1.191 \\
\hline Luxembourg & 1.028 & Romania & 1.142 \\
\hline Netherlands & 1.043 & Slovenia & 1.078 \\
\hline Portugal & 1.036 & Slovakia & 1.190 \\
\hline Spain & 1.058 & & \\
\cline { 1 - 2 } Sweden & 1.050 & & \\
\cline { 1 - 2 } United Kingdom & 0.968 & & \\
\cline { 1 - 2 } 31 December 1995 & \\
\hline
\end{tabular}

Source: own research 


\section{Conclusion}

The transition of the Czech economy from a centrally planned to market economy brought about changes in major economic indicators, including wages and incomes of the population. Their level and differentiation are going through changes in time, the shape of the wage and income distribution being altered as well.

Both these characteristics and the range of the wage and income distribution are strongly affected by the minimum wage adjustment. Workers' wages would presumably decline if the minimum wage were reduced or even abolished. The changes are naturally reflected in characteristics of the location, variability and shape of the wage and income distribution.

It is worthy of notice that the number of extremely paid people was increasing progressively over the whole research period 2002-2009. The level of the wage distribution was rising until 2008, when - in the time of economic recession - the wage growth almost stopped. Wage differentiation was also increasing throughout the period, while the skewness and kurtosis of the wage distribution were still declining.

The dual dimension of wage differentiation by gender - both within and between the groups - had to be taken into account, the latter dimension being already indicated by differences in wage growth rates.

It is expected that the deceleration in the growth rate of nominal and real income level may cause structural changes in household expenditures, cutting money spent on food, clothes and and other durable and nondurable goods while increasing energy, housing and transport costs due to relative price changes.

The research results prove that despite a much faster growth of nominal incomes, the new EU member states do not even begin to compare with the income level of the original fifteen EU countries. Weak income differentiation was a distinctive feature of the former communist regimes, having manifested itself in the wage discrepancy between skilled and less-skilled work and undifferentiated position appointment policies. Since the transition to market economy, income differentiation has been deepening significantly. A group of people with very high incomes has been growing gradually, while the skewness and kurtosis of the income distribution has still been falling.

The Czech Republic's standing among the new EU member states in terms of income is not bad at all. The country boasts of the fourth highest income level, the growth rate of income median being approximately in the middle of the ranking list. The population of neighbouring Slovakia has a slightly lower income than that of the Czech Republic. This is mainly due to the division of the former Czechoslovakia. The Slovak Republic, having lost industrial capacity and resources located in the more advanced western part of the common state, adapted to a significant reduction in the wage level as well as a deeper exchange rate depreciation. 
The financial crisis impact on the income level differed in various countries, some (e.g. the United Kingdom) having gone into an income level decline, others (e.g. Ireland) having virtually stopped their income level increase.

\section{References:}

Barber, G. M. (1988), Elemantary Statistics for Geographers. New York: GUILFORD, 1988. 513 p. ISBN 0-89862-777-X.

Bartošová, J. (2006), "Logarithmic-Normal Model of Income Distribution in the Czech Republic." Austrian Journal of Statistics. 2006, 35 (23), pp. 215-222. ISSN 1026-597x.

Bílková, D. (2008), "Application of Lognormal Curves in Modelling of Wage Distributions“. Journal of Applied Mathematics. 2008, 1 (2), pp. 341-352. ISSN 1337-6365.

Bowerman, B. L., O'connell, R. T. (1997), Applied Statistics -Improving Business Processes. Chicago: IRWIN, 1997. 1273 p. ISBN 0-256-19386-X.

Brockwell, P. J., Davis, R. A. (2002), Introduction to Time Series and Forecasting. $2^{\text {nd }}$ ed. New York: Springer, 2002. 434 p. ISBN 978-0-387-95351-9.

Cowpertwait, P. S. P., Metcalfe, A. V. (2009). Introductory Time Series with R. New York: Springer, 2009. 254 p. ISBN 978-0-387-88697-8.

Cunningham, W. (2007), Minimum Wages and Social Policy: Lessons from Developing Countries (Directions in Development). Washington: The World Bank, 2007. 132 p. ISBN 0-8213-7011-1.

Roberts, M. J., Russo, R. (1999), A Student's Guide to Analysis of Variance. New York: Routledge, 1999. 265 p. ISBN 0-415-16565-2.

Rothschild, K. W. (2005), Employment, Wages and Income Distribution: Critical Essays in Economics. New York: Routledge, 2005. 342 p. ISBN 0-203-02726-4.

Triola, M. F. (1989), Elementary Statistics. $4^{\text {th }}$ ed. Redwood City: The Benjamin/Cummings Publishing Company, 1989. 784 p. ISBN 0-8053-0271-9.

Turner, J. R., Thayer, J. F. (2001), Introduction to Analysis of Variance. Thousand Oaks: Sage Publications, 2001. 180 p. ISBN 0-8039-7074-9.

Voelker, D. H., Orton, P. Z., Adams, S. V. (2001), Statistics. New York: Wiley Publishing, 2001. 154 p. ISBN 0-7645-6388-2.

Waltman, J. L. (2000), The Politics of the Minimum Wage. Urbana: University of Illinois Press, 2000. 172 p. ISBN 0-252-02545-8.

Wolff, E. N. (2009), Poverty and Income Distribution, $2^{\text {nd }}$ ed. West Sussex: Wiley-Blackwell, 2009. 650 p. ISBN 978-1-4051-7660-6.

Internet sources:

http://epp.eurostat.ec.europa.eu/portal/page/portal/eurostat/home

http://www.czso.cz 